\title{
Contents, Vol. 35, 1973
}

\section{Contents III}

Wijngaarden, H. A. van and Fokkens, J. K. (Utrecht): The Principle of the

'Aerosol Sonique' 111

Crifò, S. (Rome): Laryngeal Idiopathic Amyloidosis 117

Book Reviews · Buchbesprechungen . Livres nouveaux

Varia 128

No. 3-4

Jongkees, L. B. W.: Dedication to Prof. Gerlings 129

Arslan, M. (Padova): Ultrasonic Hypophysecytomy in Acromegaly. Report of

41 Cases 134

Bottema, T. (Amsterdam: The Esthesioneuroepithelioma 141

Crabbé, F. (Brussel): Present Trends in the Evaluation of Vestibular Function 146

Damsté, P. H. (Utrecht): Vocal Disorders. A Guide to their Diagnosis

Deinse, J. B. van (Den Haag): Some Remarks about the Covering of the

Singing Voice 154

Grobben, L. M. (Utrecht): Pitch of Short Tones 158

Ham, H. J. (Utrecht): Modern Radiotherapy in Carcinoma of the Larynx 164

Hoeksema, P. E. (Groningen): Kelly-Paterson Syndrome and Carcinoma 167

Jongkees, L. B. W. and Oosterveld, W. J. (Amsterdam): Sinusoidal Opto-kinetic Stimulation: the Use of a Subtractor for the Pendulum-Swing

Test 171

Kupperman, R. (Renkum): The Complexity of Cochlear Adaptation

Lansberg, M. P. (Zeist): Alternobaric or Pressure Vertigo and the Pseudo-Positive Fistula

Symptom as a Reflex Phenomenon: Reflexogenic

Vertigo and Nystagmus 184

Ledoux, A. (Liège): Personal Observation of Cochlear Traumas 189

Leibbrandt, E. H. M. and Leibbrandt, C. C. (Utrecht): Anesthesia in Laryngectomy 195

Majer, E. H. and Rieder, W. (Wien): Laryngectomy with Preservation of the Air Passages 200

Marres, E. H. M. A.; Huygen, P. L. M., and de Jong v. d. Brand, O. W. J. M.

(Nijmegen): The Classification of Audiograms in Otosclerosis. Pre

liminary Report 205

Mounier-Kuhn, P. (Lyon): On the Maturation of Human Auditory Func

tion 210

Pfaltz, C. R. (Basle): The Indication of Infraorbital Nerve Decompression 214

Rietjens, J. H. (Utrecht): The Pre-Epiglottic Space in Laryngeal Cancer 217

Sedee, G. A. (Utrecht): Facial Nerve and Dysplasia of the Temporal Bone ... 222 Struben, W. H. (Rotterdam) Endoscopic Treatment of Esophageal Diverti- 
cula 229

Venker, H. (Amersfoort): Sonomanometric Investigation of the Eustachian

Tube Function and Tympanoplasty 233

Venker, J. (Liempde): The Missing Incus 237

Contents

No.1

Goumaz, C.-F. (Lausanne): Laryngotracheal Sequelae of Prolonged Intubation

in Newborn Infants

1

Ulrich, K. and Kessler, L. (Magdeburg): Stomatological Findings after

Operations of the Maxillary Sinus in Childhood 15

L $\gamma$ nder-Aronson, S. and Henrikson, C. O. (Stockholm): Radiocephalometric Analysis of

Anteroposterior Nasopharyngeal Dimensions in 6- to 12-

Year-Old Mouth Breathers Compared with Nose Breathers 19

Tos, M. (Copenhagen): Post-Traumatic Cerebrospinal Fluid Otorrhoea 30

Escher, F. und Michel, E. (Bern): Die Ertaubung nach dem Spracherwerb ... 36

Kovar, M. (New York, N.Y.): The Inner Ear in Diabetes Mellitus 42

Myyoshi, T. and Pfaltz, C. R. (Basel): Upon the Correlation between the

Optokinetic Stimulus and the Induced Optokinetic Nystagmus. I. In

fluence of O.K. Targets 52

Erratum $\quad 64$

No. 2

Groen, J. J. (Utrecht): Pure Tone Audiometry and Whispered Voice Test.

Conformities and Differences in Test Results 65

Pfaltz, C. R.; P yffko, P., and Mishra, B. (Basel): Central Compensation of

Vestibular Dysfunction. II. Neuronal and Central Lesions 71

Calseyde, P. Van de; Ampe, W., and Depondt, M. (Bruges): Use of the

Torsion Swing Test in a Follow-up Study of the ENG Registration

In Cases of Unilateral Labyrinthectomy 83

Blattler, W.; Northrop, C, and Montandon, A. (Geneva): A Case Report

of Ménière's Disease, Emphasizing the Extent of Endolymphatic

Hydrops 90

Scheibe, F.; Gerhardt, H.-L; Hache, U., and Haupt, H. (Berlin): Thin-Layer

Chromatographic Investigation of the Lipids of Inner Ear Tissues

and Perilymph of Guinea Pig 96

Mair, I. W. S.; Natvig, K.; Maurer, H.-J., and Ødegaard, H. I. (Tromsø):

The Globus Symptom 104

$\Gamma \mathrm{V}$ Contents

Verbiest, H. (Utrecht): A Short Review of the Collaboration between the

Utrecht Departments of Oto-Rhino-Laryngology and of Neurosurgery

and a Contribution to Some Macro-Surgical Aspects of Transphenoi-

dal Hypophysectomy 241

Wit, G. de (Amsterdam): The Flying Enterprise Symptom 248

Varia 252

No. 5

Fluur, E. (Stockholm): The Reason why the Patient with Acute Labyrinthine

Destruction Lies on his Sound Ear 253 
Thomsen, J. and Zilstorff, K. (Copenhagen): Vestibular Hyperreactivity in the Differential Caloric Test 258

Vigneri, J. M.; Juhn, S. K., and Singer, L. (Minneapolis, Minn.): Calcium and Fluoride Metabolism in Auditory Ossicles 266

Portmann, M. (Bordeaux): Surgery of the Internal Auditory Canal 272

Huizing, E. H. (Leiden): The Early Descriptions of the So-Called Tuning Fork

Tests of Weber and Rinne. I. The 'Weber Test' and its First Descrip

tion by Schmalz 278

Lynder-Aronson, S. (Stockholm): Effects of Adenoidectomy on Mode of

Breathing, Size of Adenoids and Nasal Airflow , 283

Kornblut, A. D.; Ilse, H., and Haubrich, J. (Göttingen): Parotid Lymph-

angioma: A Congenital Tumour 303

Book Reviews · Buchbesprechungen . Livres nouveaux 315

Varia 316

No. 6

Steix, P. M. (Liverpool): Pharyngeal Reconstruction Using the Delto-Pectoral

Flap 317

Obinwa, O. (Basel): Appraisal of Advances in Anaesthetic Management for

Endolaryngeal Examinations and Microsurgery 324

Jeppsson, P.-H. and Lindström, J. (Göteborg): Carcinoma of the External Ear 336

Morymitsu, T. and Hayashida, K. (Fukuoka): Surgical and Histological Find

ings of the Stapes Associated with Van der Hoeve Syndrome in a

Japanese Boy 342

Miyoshi, T. and Pfaltz, C. R. (Basel): Studies on the Correlation between

Optokinetic Stimulus and Induced Nystagmus. 2. The Influence of

the Visual Fields upon the Optokinetic Response $\quad 350$

Hammelburg, E. (Wassenaar): Noise, Man and Law 363

Varia 371

Subject Index 372

Author Index 375 